\title{
EQUITABLE JURISDICTION OF THE PROVINCIAL COURT OF ALBERTA (CIVIL DIVISION)
}

\author{
LINDA A. TAYLOR and DAVID M. WOOD'
}

This article is concerned with the issue of whether the Provincial Court of Alberta (Civil Division) possesses any equitable jurisdiction. The authors first provide a history of equity and its fusion with law, and the impact of that fusion in Canada. The authors then examine the jurisdiction of the Provincial Court of Alberta (Civil Division) and conclude that, as an inferior statutory court, it can have no inherent substantive jurisdiction, only an inherent procedural jurisdiction. However, the Legislature can enlarge the Court's jurisdiction by statute (although the authors point out that there are limits on the jurisdiction that can be granted to an inferior statutory court). The authors then argue that, contrary to common belief, the Provincial Court of Alberta (Civil Division) does possess a limited equitable jurisdiction. They base this submission first on the wording of the Alberta Provincial Court Act, which allows the court to hear and adjudicate any claim for debt or damages (and unlike in other Alberta statutes, the Court in those situations is not specifically barred from granting equitable relief). Secondly, they submit that the granting of limited equitable jurisdiction is necessarily incidental to the achievement of broad policy goals related to the establishment of the Court. Finally, the authors compare the jurisdiction of the Provincial Court of Alberta (Civil Division) to that of the Small Claims Courts in Ontario and British Columbia.
Les auteurs tentent de déterminer si la Cour provinciale de l'Alberta (Chambre civile) détient une quelconque juridiction d'équité. Ils proposent d'abord un historique de l'équité et de sa fusion avec le droit, et en examinent l'incidence au Canada. Ils se penchent ensuite sur la compétence de la Cour provinciale de l'Alberta (Chambre civile) et concluent que, en tant que cour inférieure créée par la Loi, elle ne peut avoir aucune juridiction inhérente quant au fond - seulement en matière de procédure. Cependant, le champ de compétence de la cour peut être élargi au terme d'une loi de la Législature (même s'il existe certaines limites). Les auteurs soutiennent ensuite que, contrairement aux idées recues, la Cour provinciale de l'Alberta (Chambre civile) détient bien une juridiction d'équité limitée. Ils fondent leur argument sur la formulation de la Alberta Provincial Court Act, qui permet d̀ la cour d'entendre et de régler toute demande en dommages-intérêts ou créance (et, contrairement d̀ ce que stipulent d'autres lois albertaines, la cour n'est pas expressément empéchée d'accorder des mesures de redressement équitable). En second lieu, les auteurs estiment que cette juridiction d'équité limitée est nécessairement accessoire à la réalisation d'objectifs généraux liés à l'établissement de la cour. En dernier lieu, les auteurs comparent la compétence de la Cour provinciale de l'Alberta (Chambre civile) et celle de la cour des petites créances en Ontario et en Colombie-Britannique.

\section{TABLE OF CONTENTS}

I. INTRODUCTION .................... 593

II. EQUITY, CHANCERY AND THE FUSION

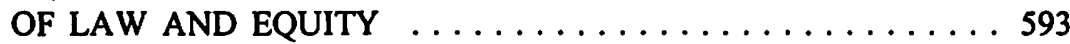

III. FUSION OF LAW AND EQUITY IN CANADA $\ldots \ldots \ldots \ldots 597$

IV. THE PROVINCIAL COURT OF ALBERTA

(CIVIL DIVISION) $\ldots \ldots \ldots \ldots \ldots \ldots \ldots \ldots \ldots \ldots \ldots$

V. INHERENT JURISDICTION AND

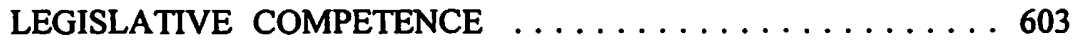

Code Hunter Wittmann, Calgary, Alberta. Thanks to Marlis $M$. Schoenemann for her invaluable research assistance. 


\title{
VI. STATUTORY JURISDICTION OF THE PROVINCIAL COURT OF ALBERTA
}

(CIVIL DIVISION)

VII. EQUITABLE JURISDICTION OF THE

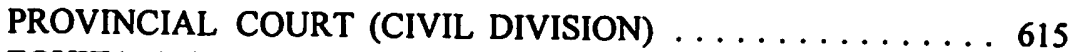

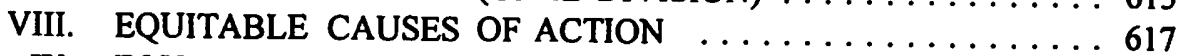

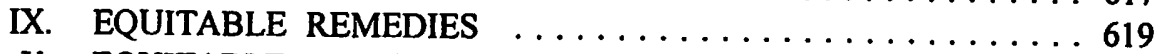

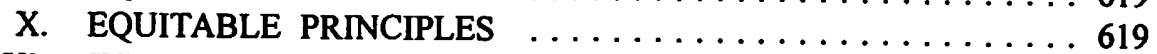

XI. JURISDICTION REGARDING PREROGATIVE WRITS $\ldots \ldots 620$

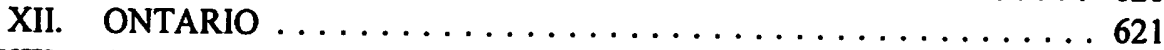

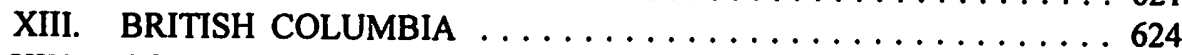

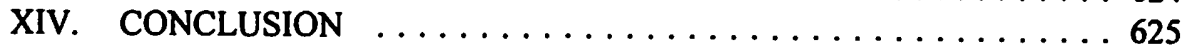

\section{INTRODUCTION}

This article addresses the question whether the Provincial Court of Alberta (Civil Division) has any equitable jurisdiction, and concludes that an argument may be made that it has a limited equitable jurisdiction.

This article begins with a brief history of equity and fusion and the effect of fusion in Canada, before turning to a discussion of the jurisdiction of the Provincial Court of Alberta (Civil Division), including the notion of "inherent jurisdiction" and the competence of legislatures to transfer powers or jurisdiction from superior to inferior courts. Finally, by way of comparison it will examine the jurisdiction of Small Claims Courts in Ontario and British Columbia in light of the statutory framework of those provinces.

\section{EQUITY, CHANCERY AND THE FUSION OF LAW AND EQUITY}

\begin{abstract}
Never can there come fog too thick, never can there come mud and mire too deep, to assort with the groping and floundering condition which this High Court of Chancery, most pestilent of hoary sinners, holds this day in the sight of heaven and earth.... This is the Court of Chancery; which has its decaying houses and its blighted lands in every shire; which has its worm-out lunatic in every madhouse, and its dead in every churchyard; which has its ruined suitor, with his slipshod heels and threadbare dress, borrowing and begging through the round of every man's acquaintance; which gives to monied might the means abundantly of wearying out the right; which so exhausts finances, patience, courage, hope; so overthrows the brain and breaks the heart; that there is not an honourable man among its practitioners who would not give - who does not often give - the waming, "Suffer any wrong that can be done you rather than come here!"1
\end{abstract}

This description of Chancery by Charles Dickens in the opening chapter of Bleak House shows the Court of Equity in a most unflattering light. By the close of the nineteenth century, however, the warts and wrinkles of Chancery were apparent to all. The Court of Chancery, once hailed as a speedy forum of fairness and conscience, had 
become what one contemporary commentator called a court of oyer sans terminer, a witty reference to the Assize Court of oyer et terminer, or "hear and decide." 2

Equity is an Aristotelian concept, intended to temper the harshness of law which sometimes results by reason of its universality. The Chancery began as the Royal Secretariat - a department of state which derived its power from possession of the Great Seal. ${ }^{3}$ The Chancery issued and sealed royal decrees and the original common law writs. The judicial activity of Chancery arose from the jurisdiction of the King's Council to deal with bills of complaint. The Council began to pass these bills on to the Chancellor, and by at least 1400 , plaintiffs began to submit their bills of complaint directly to the Chancellor. ${ }^{4}$ When the Chancellor received such a bill, he would generally issue a new form of original writ. Although the original writs could act as a form of precedent, Chancery clerks customarily issued a new original writ for each new action. By the middle of the thirteenth century, however, there were so many original writs that the Provisions of Oxford 1258 forbade the issuance of any new writs, and the common law forms of action were born. If a plaintiff could not find an existing original writ that fit his situation, the plaintiff had no remedy at law. ${ }^{5}$

When, after the decree of 1258 , the Chancellor could not issue new original writs, the only general remedy in respect of a private bill of complaint was for the plaintiff to submit such bill to Parliament and hope for an Act of that House. Because this was wholly unworkable, and because plaintiffs had to pay to start an action, the Chancellor was disinclined to send away plaintiffs who had no remedy at law using an original writ. Instead, the Chancellor began to hear the complaints ad hoc, granting by way of a decree specific remedies which had no precedential value and which only bound the parties to the complaint - they were in personam. By the time of Henry VII (late 1400 s), Chancellor Moreton was able to boast proudly that "nullus recedat a curia cancellariae sine remedio" - no one leaves the Court of Chancery without a remedy. ${ }^{6}$

Equity operated on the basis of what was fair between the parties before the Court, rather than on what the common law precedents dictated. Because the remedies were personal, the Chancellor could exercise the "King's conscience," which was of course nothing more than the Chancellor's discretion. For example, in law a sealed bond was incontrovertible evidence of a debt. Payment was no defence. The hapless debtor who failed to cancel or destroy the bond upon paying the debt had no answer at law to a claim by the creditor on the debt. In equity, however, the Chancellor would listen to the parties and render a fair decision. It was not that the law held that the debt was due twice. Rather, the rule regarding bonds was set, and could not be broken without impairing the certainty of the law. Of course, unprincipled creditors could take advantage of debtors this way, but this was a matter of conscience and not law. If the

J.H. Baker, An Introduction to English Legal History (Toronto: Butterworths, 1990) at 130.

Ibid. at 144.

Ibid. at 117.

Ibid. at 66 .

Anon. (1489), Y.B. Hil. 4 Hen. 7, pl. 8, fol. 5. 
debtor wanted justice, he had to seek the assistance of the court of conscience and not the court of law.?

Over the centuries, disgruntled suitors began to complain about the unprincipled nature of equity. Selden wrote in 1654 that:

Equity is A Roguish thing, for Law wee have a measure, know what to trust too. Equity is according to the conscience of him that is Chancellor, and as that is larger or narrower soe is equity. Tis all one as if they should make the Standard for the measure we call A foot, to be the Chancellor's foot; what an uncertain measure would this be; One Chancellor has a long foot, another A short foot a third an indifferent foot; tis the same thing in the Chancellor's Conscience.

Equity was not intended to compete with the law, nor was it to challenge the authority of the law. F.W. Maitland wrote in Equity, also, the Forms of Action at Common $L a w^{9}$ that equity was not meant to be a comprehensive legal system; it was a collection of "disconnected doctrines, disconnected appendixes to or glosses on the common law."10 It developed in response to problems or areas of unfairness in the law and was meant to operate in situations where the rigidity and limitations of law prevented justice; in this sense equity was said to "follow the law." Chancery soon became a busy court.

One of the reasons for the early popularity of Chancery was its uncomplicated procedure. Writs and formalistic pleadings were not required in Chancery. Instead, a plaintiff started an action using a simple bill of complaint (in English, no less). Process was begun using a subpoena, to which our modern pleadings trace their roots. There were no juries in Chancery, since the Chancellor was being called upon to exercise the King's conscience. Interlocutory applications began to be heard by officials called Masters; affidavit evidence was accepted; and parties could be examined as witnesses. This last point seems minor today, but originally juries were chosen for their knowledge of the dispute, and the litigants were not entitled to testify. Finally, Chancery was always open and was not tied to the Law Terms and return-days."

The salaries of court officials were almost exclusively derived from fees levied from suitors. Consequently, each court jealously guarded its jurisdiction. As Chancery became more popular, jurisdictional disputes with the common law courts became more common. These disputes continued from time to time until in 1616 the matter came to a head. Lord Ellesmere was Chancellor and he began to encourage suitors disappointed in law to re-open their suits in Chancery. ${ }^{12}$ Sir Edward Coke, Chief Justice of the King's Bench, began to release by writ of habeas corpus prisoners committed by Ellesmere for contempt, and in turn encouraged these equitable contemners to prosecute their

S.F.C. Milson, Historical Foundations of the Common Law, 2d ed. (London: Butterworths, 1981) at 86.

$8 \quad$ F. Pollock, ed., Table Talk of John Selden (London: Quaritch, 1927) at 43.

- (Cambridge: Cambridge University Press, 1916).

10 Ibid. at 21.

"Baker, supra note 2 at 119-20.

$12 \quad$ Ibid. at 125 . 
opponents in King's Bench for "impeaching the judgments of the King's courts." 13 After an unsuccessful attempt by one such suitor to indict several high officials including the Chancellor, Lord Ellesmere petitioned the King. Coke was dismissed and the King issued a decree stating that Chancery had jurisdiction to entertain suits after judgment at law. ${ }^{14}$ This decree and the Earl of Oxford's Case ${ }^{15}$ likely form the bases for the maxim that whenever there is a conflict between law and equity, equity prevails. In the Earl of Oxford's Case, Lord Ellesmere said:

[T] hat Mens Actions are so divers and infinite, That it is impossible to make any general Law which may aptly meet with every particular Act, and not fail in some Circumstances.

The Office of the Chancellor is to correct Mens Consciences for Frauds, Breach of Trusts, Wrongs and Oppressions, of what Nature soever they be, and to soften and mollify the Extremity of the Law. ${ }^{\text {t6 }}$

In the end, the very success of the Chancery was its downfall. Faced with thousands of suitors, the court began to adopt routine attitudes to commonly recurring situations. Decisions began to be reported during the time Lord Ellesmere was on the woolsack. ${ }^{17}$ Equity began to harden: mortgages and trusts became governed by a strict body of rules; and the Court refused to amend harsh contracts, ruling in Maynard v. Moseley ${ }^{18}$ that "the Chancery mends no man's bargain."' ${ }^{\prime \prime}$ Lord Eldon C. was prompted to remark in Gee v. Pritchard" that "[n]othing would inflict on me greater pain, in quitting this place, than the recollection that I had done any thing to justify the reproach that the equity of this Court varies like the Chancellor's foot."21

The simple procedures which formerly made Chancery an attractive forum had likewise become fustian. The Chancery clerks were paid through fees, and as every step generated more fees, there was no reward for efficiency. Paid by the page, clerks began to lengthen Masters' reports by reciting the whole of the proceedings in a "whereas" clause before turning to the actual report. Suitors were made to purchase documents and copies of documents they neither wanted nor needed, and which could only be prepared by the clerks. J.H. Baker noted in An Introduction to English Legal History 22 that Chancery clerks developed such large handwriting and wide margins that they could transform what began as six pages into forty.

Finally, in 1824 Lord Eldon was directed to head a Commission to look into delays in Chancery. Morgan v. Lord Clarendon was begun in 1808, yet sixteen years later it

Ibid. at 125.

Ibid. at 125-26.

(1615), 1 Ch. Rep. 1, 21 E.R. 485.

Ibid. at 6-7.

See Duchess of Suffolk v. Herenden (1560) cited in J.H. Baker, "The Use Upon a Use in Equity 1558-1625" (1977) 93 L.Q.R. 33 at 36.

(1676), 3 Swan 651, Nottingham L.C.

lbid. at 655 .

(1818), 2 Swan 402.

Ibid. at 414.

Supra note 2 at 13. 
was still in the interlocutory stages, with court costs of $£ 3,719$. Some $£ 39,000,000$ languished in Chancery coffers - funds paid into court either awaiting the completion of some case or other, or abandoned by weary or bankrupt litigants. ${ }^{23} \mathrm{~A}$ major source of difficulty was that there were only two judges in Chancery. Legislative reforms were undertaken. The Common Law Procedure Act 1854 gave the Chancery the jurisdiction to award damages, while the common law courts were given the ability to take notice of certain equitable principles and to dispense equitable remedies. Early in the next decade, a Judicature Commission was struck. The Judicature Commission delivered its report in 1869 and recommended fusion of law and equity. This fusion was legislated in the Judicature Act of 1873. This Act created the Supreme Court of Judicature, whose judges were empowered to administer both law and equity. ${ }^{24}$

\section{FUSION OF LAW AND EQUITY IN CANADA}

Fusion came into effect in England in the mid 1870's and shortly thereafter found its way to Canada. Ontario was the first province to follow, enacting the Ontario Judicature Act. ${ }^{25}$

In Alberta, fusion is found in the Judicature $A c t,{ }^{26}$ which provides that:

4 The judges of the Court have and shall use, exercise and enjoy all the powers, rights, incidents, privileges and immunities of a judge of a superior court of record, and all other powers, rights, incidents, privileges and immunities as amply and as fully to all intents and purposes as they were on and before July 15, 1870, had, used, exercised and enjoyed in England by any of the judges of the following courts:

(a) the Superior Courts of Law or Equity;

(b) the Court of Exchequer as a court of revenue;

(c) the Court of Probate;

(d) the Courts created by Commissions of Assize, of Oyer and Terminer and of Gaol Delivery, or any of those commissions;

(e) any other superior court or court of record.

5(1) For the administration of the law, the Court possesses (in addition to any other jurisdiction, rights, powers, incidents, privileges and authorities that immediately before the organization of the Supreme Court of Alberta were vested in or capable of being exercised within Alberta by the Supreme Court of the Northwest Territories) the jurisdiction that on July 15, 1870, was in England vested in

Ibid. at $\mathbf{1 3 0 - 3 1}$.

Ibid.

S.O. 1881 , c. 5 .

R.S.A. 1980 , c. J-1. 
(a) the High Court of Chancery, as a common law court as well as a court of equity, including the jurisdiction of the Master of the Rolls as a judge or master of the Court of Chancery, and any jurisdiction exercised by him in relation to the Court of Chancery as a common law court,

(b) the Court of Queen's Bench,

(c) the Court of Common Pleas at Westminster,

(d) the Court of Exchequer as a court of revenue as well as a common law court,

(e) the Court of Probate,

(f) the courts created by Commission of Assize, of Oyer and Terminer and of Gaol Delivery, or any of those commissions, and

(g) any other superior court or court of record.

(3) For the purpose of removing any doubt, but not so as to restrict the generality of subsections (1) and (2), it is declared that the Court has the like jurisdiction and powers that by the laws of England were, on July 15, 1870, possessed and exercised by the Court of Chancery in England in respect of

(a) fraud, mistake and accident,

(b) all matters relating to trusts, executors and administrators, partnerships and accounts, mortgages and awards, or to infants, idiots or lunatics and to the estates of infants, idiots or lunatics,

(c) the staying of waste,

(d) compelling specific performance of agreements and contracts,

(e) compelling discovery of concealed papers or evidence, or such as might be wrongfully withheld from the party claiming the benefit of them,

(f) preventing the multiplicity of actions,

(g) decreeing the issue of letters patent from the Crown to rightful claimants,

(h) decreeing the repeal of and making void letters patent issued by mistake or improvidently or through fraud,

(i) the administration of justice where there exists no adequate remedy at law, and 
(j) a grant of injunction to stay waste in a proper case notwithstanding that the party in possession claims by an adverse legal title.

(4) The rules of decisions in matters mentioned in subsection (3)[,] except where otherwise provided, shall be the same as governed the Court of Chancery in England in like cases on July 15, 1870.

"Court" is defined in s. 1 of the Judicature Act to mean the Court of Queen's Bench and the Court of Appeal. Section 8 gives the Court the power to grant "all remedies whatsoever" with respect to "any and every legal or equitable claim." Section 20 provides as follows:

20 In all cases in which the Court has jurisdiction to entertain an application

(a) for an injunction against

(i) a breach of a covenant, contract or agreement, or

(ii) the commission or continuance of a wrongful act,

or

(b) for the specific performance of a covenant, contract or agreement,

the Court if it thinks fit may award damages to the injured party either in addition to or in substitution for the injunction or specific performance, and the damages may be ascertained in any manner the Court may direct, or the Court may grant any other relief that it considers just.

What was the effect of fusion? One view was that it was only the courts which were fused and not the two systems. That is, although superior courts were entitled to administer both law and equity, there were still two separate systems. In his book Principles of Equity, W. Ashburner wrote of law and equity that "the two streams of jurisdiction, though they run in the same channel, run side by side and do not mingle their waters." ${ }^{\text {27 }}$ Lord Diplock commented on this passage in United Scientific Holdings Ltd. v. Burnley Borough Council as follows:

By 1977, this metaphor had in my view become both mischievous and deceptive. The innate conservatism of English lawyers may have made them slow to recognise that by the Supreme Court of Judicature Act 1873 the two systems of substantive and adjectival law formerly administered by courts of law and Courts of Chancery (as well as those administered by courts of admiralty, probate and matrimonial Causes), were fused. ${ }^{28}$

It is not enough that the result of fusion be that judges now simply wear two hats; one as a judge in law, the other as a judge in equity. As Stephen Toulmin wrote in "Equity and Principles": 
Equity means doing justice with discretion: around, in the interstices of, and in the areas of conflict between our laws, rules, principles and other general formulae. It means being responsive to the limits of all such formulae, to the special circumstances in which one can properly make exceptions, and to the trade-offs required where different formulae conflict. ${ }^{29}$

In 1986, a justice of the Ontario Court of Appeal was moved to remark in LeMesurier v. Andrus that the "fusion of law and equity is now real and total."30

However, the issue of the effect of fusion is still very much alive, notably in the context of breach of fiduciary duty.

Although prior to passage of the Lord Cairns' Act courts of equity did not award damages, they had jurisdiction to award monetary compensation. For example, where a breach of trust resulted in a loss to the trust estate, "equitable compensation" could be awarded to the beneficiaries of the trust. Such remedy appears not to be subject to certain of the limiting principles that operate to restrict an award of damages at common law. In Re Dawson, Street J. contrasted the principles as follows:

The obligation of a defaulting trustee is essentially one of effecting a restitution to the estate. The obligation is of a personal character and its extent is not to be limited by common law principles governing remoteness of damage.

... Caffrey v. Darby (1801), 6 Ves.Jun. 488; 31 E.R. 1159, is consistent with the proposition that if a breach has been committed then the trustee is liable to place the trust estate in the same position as it would have been if no breach had been committed. Considerations of causation, forseeability and remoteness do not readily enter into the matter.

... The principles embodied in this approach do not appear to involve any inquiry as to whether the loss was caused by or flowed from the breach. Rather the inquiry in each instance would appear to be whether the loss would have happened if there had been no breach. ${ }^{31}$

This statement was quoted by Wilson J. in Guerin v. The Queen wherein it was held that the principles applicable to awards of equitable compensation against trustees were similarly applicable to awards for breach of fiduciary duty. ${ }^{32}$

In 1991 the Supreme Court of Canada had occasion to consider further the remedy of equitable compensation for breach of fiduciary duty and whether common law limiting principles should apply. In Canson Enterprises Ltd. v. Boughton \& Co. ${ }^{33}$ one of the defendants was a lawyer who had acted for both the vendors and the joint venturing plaintiffs in the purchase of a property the plaintiffs intended to develop as a warehouse. The purchase price was $\$ 525,000$. What the plaintiffs did not know, but

(1982) 20 Osgoode Hall L.J. 1 at 8-9.

(1986), 25 D.L.R. (4th) 424 at 432 (leave to appeal to S.C.C. refused (1986) 74 N.R. 239).

(1966), 84 W.N. (Pt.l) (N.S.W.) 399 at 404.

(1984), 13 D.L.R (4th) 321 at 365 (S.C.C.).

[1991] 3 S.C.R. 534 [hereinafter Canson]. 
what the lawyer and one of the joint venture partners knew, was that the vendors were selling the land to an intermediate buyer for $\$ 410,000$. The lawyer documented the purchase so that the "flip" and secret profit was hidden. The purchase was completed and the warehouse constructed. Unfortunately, the warehouse sank because the piles supporting the building were inadequate. The joint venturers successfully sued the soils engineer and pile driving company in negligence, but together two of the joint venturers suffered a shortfall of $\$ 1$ million after enforcing the judgment. These two sued to recover the shortfall, alleging breach of fiduciary duty and, alternatively, deceit against the lawyer.

The matter proceeded on the basis of a stated case and an agreed statement of facts. The sole issue was whether and what damages were recoverable. The trial judge ruled that deceit had not been made out but that the lawyer had breached his fiduciary duty. He held that compensation for the breach of fiduciary duty was to be calculated as it would be in a claim for damages for fraud, and that the plaintiffs were entitled to the difference between their purchase price and the value of the land (i.e. the secret profit). This was upheld by the Court of Appeal.

Before the Supreme Court of Canada, the plaintiffs argued that when awarding equitable compensation rather than common law damages, limiting principles such as remoteness, intervening cause and foreseeability had no application. The plaintiffs argued that a court of equity in exercising its jurisdiction to compensate for loss suffered as a result of breach of fiduciary duty was engaged in a process of restitution, seeking to put the plaintiff in as good a position as he or she would have been in had the breach not occurred. The defendants argued, inter alia, that the fusion of law and equity resulted in the common law limiting principles being applicable to an award of equitable compensation.

Although the Supreme Court of Canada unanimously dismissed the appeal, the court was divided in its approach to the effect of fusion. The nine member panel delivered three judgments (although Wilson J. sat, she did not take part in the decision). La Forest J. wrote for four of the remaining eight judges. According to La Forest J. the measure of compensation would vary with the nature of the breach of the equitable duty, and the amount of compensation ought to be referable to the harm suffered from the breach of fiduciary duty. This case, wrote his lordship, was a breach of a duty to disclose the secret profit and was different from cases where the fiduciary had misused or lost the plaintiff's property. He reasoned that since there was little authority on the equitable jurisdiction to award compensation involving cases where additional harm had been occasioned by third parties, an effect of fusion was that courts ought to respond with principles drawn from similar situations under the common law. In this case, ruled La Forest J., the similar common law area was fraud, and common law limiting principles militated against recovery from the lawyer of loss caused by the soil engineer and pile driving company. His lordship explained:

I am aware that reservations have been expressed in some quarters about this fusion or, perhaps more accurately, mingling of law and equity; see Hanbury and Maudsley, Modern Equity (12th ed. 1985), at p. 22-26. But no case was brought to our attention where it has led to confusion, and there are many 
cases, some of which I have discussed, where it has made possible a just and reasonable result. It simply provides a general, but flexible, approach that allows for direct application of the experience and best features of both law and equity, whether the mode of redress (the cause of action or remedy) originates in one system or the other. There might be room for concem if one were indiscriminately attempting to meld the whole of the two systems. Equitable concepts like trusts, equitable estates and consequent equitable remedies must continue to exist apart, if not in isolation, from common law rules. But when one moves to fiduciary relationships and the law regarding misstatements, we have a situation where now the courts of common law, now the courts of equity moved forward to provide remedies where a person failed to meet the trust or confidence reposed in that person. There was throughout considerable overlap. In time the common law outstripped equity and the remedy of compensation became somewhat atrophied. Under these circumstances, why should it not borrow from the experience of the common law? Whether the courts refine the equitable tools such as the remedy of compensation, or follow the common law on its own terms, seems not particularly important where the same policy objective is sought.

Where a situation requires different policy objectives, then the remedy may be found in the system that appears more appropriate. This will often be equity. Its flexible remedies such as constructive trusts, account, tracing and compensation must continue to be moulded to meet the requirements of faimess and justice in specific situations. ${ }^{34}$

Although McLachlin J. (Lamer C.J.C. and L'Heureux-Dube' J. concurring) agreed in the result, she said that there was no need to travel outside equity and visit tort and contract law. Contract law, she commented, strikes a balance between independent and self-interested parties, whereas equity protects the relationship between a dependent party and another who is obliged to avoid a conflict between duty and self-interest. The court ought not to borrow from tort law, she said, because this might lead to "ready answers" inappropriate in the context of fiduciary duties. In her view, borrowing from the common law when interpreting an equitable remedy obscured the restitutionary nature of compensation. She noted that equity, like the common law, had its own limiting principles. While foreseeability was not a factor, equitable compensation was limited to losses flowing from the fiduciary's acts in relation to the interest the fiduciary undertook to protect. Addressing the issue of damage done by third parties, she stated:

The requirement that the loss flow from the breach also assists in determining responsibility for the acts of strangers or third parties. If the breach permits a third party to take an unlawful advantage causing loss to the plaintiff, the fiduciary will be liable because there is a causal link between the breach and the loss.... Where, on the other hand, the plaintiff suffers loss as a result of the act of a third party after the fiduciary's obligation has terminated and the plaintiff has taken control of the property, the result will be otherwise. ${ }^{35}$

What is clear from this case is that the effect of fusion, and the distinction and overlap between law and equity, are still not settled. 


\section{THE PROVINCIAL COURT OF ALBERTA (CIVIL DIVISION)}

The Provincial Court of Alberta is a statutory court. It owes its existence to and is restricted by its enabling legislation. Unlike the so-called "section 96 courts," such as the Court of Queen's Bench, the jurisdiction of the Provincial Court can be enlarged and reduced by statute, although there are limits to the jurisdiction which can be given to an inferior statutory court.

\section{INHERENT JURISDICTION AND LEGISLATIVE COMPETENCE}

In "The Inherent Jurisdiction of the Court," Isaac Jacob defined "inherent jurisdiction" to mean:

a reserve or fund of powers, a residual source of powers, [upon] which the court may draw ... as necessary whenever it is just and equitable to do so, and in particular to ensure the observance of the due process of law, to prevent improper vexation or oppression, to do justice between the parties and to secure a fair trial between them. ${ }^{36}$

It is generally accepted that statutory or "inferior" courts and tribunals possess no inherent substantive jurisdiction. Such a court's substantive jurisdiction must be derived from legislation. However, there are limits to the jurisdiction that a legislature may bestow on a statutory court.

Where at common law an inferior court lacks the power to do something, the legislature may by express and unambiguous language nevertheless confer upon that court the power to do that thing. An example is the power of a court to punish for contempt ex facie. At common law, only superior courts could punish contemnors for contempt occurring outside the presence of the court. Canadian legislatures have attempted to give this power to inferior and statutory courts and tribunals on several occasions. The Supreme Court of Canada ruled in C.B.C. v. Quebec Police Commission $^{37}$ that the Quebec Police Commission did not have the power to conduct an inquiry concerning or punish a contempt not committed in its presence, notwithstanding that its enabling legislation conferred on the Commission members the powers of a superior court judge. Beetz J. (Laskin C.J.C., Ritchie, Spence, Pigeon, Estey and Pratt JJ. concurring), held that the Quebec legislature could not constitutionally give the Commission the power to inquire into and punish contempt $e x$ facie, as this infringed s. 96 of the Constitution Act, $1867 .^{38}$ Section 96 provides as follows:

96 The Governor General shall appoint the Judges of the Superior, District, and County Courts in each Province, except those of the Courts of Probate in Nova Scotia and New Brunswick. 
After reviewing English and Canadian authorities, Beetz J. concluded that the contempt ex facie power was enjoyed exclusively by the superior courts. ${ }^{39}$ Furthermore, he ruled that any attempt to bestow on an inferior court or tribunal a power exclusively within the jurisdiction reserved to the superior courts as of 1867 contravened s. 96 of the Constitution. Although he agreed in the result, Dickson J. (as he then was), writing for himself and Martland J., stated that a legislature may, through a "clear and unambiguous statutory provision," invest an inferior tribunal with a power otherwise enjoyed exclusively by a superior court. ${ }^{40}$

In Chrysler Canada Ltd. v. Canada (Competition Tribunal), the same issue arose, this time in the context of the Competition Tribunal. Gonthier J., delivering the majority judgment (La Forest, L'Heureux-Dube', Sopinka and Cory JJ. concurring), commented that:

When dealing with common law rules on the jurisdiction of superior courts, it is important to distinguish between enactments which deprive superior courts of their jurisdiction or privative clauses, and enactments which convey part of the jurisdiction of superior courts to another tribunal, while not extinguishing the jurisdiction of superior courts. In the former case, courts have insisted on a narrow construction, since the citizen may be deprived of a recourse to the superior court. In the latter case, I would think that there is little point in insisting upon precise formulae to the extent that the intention of Parliament may be thwarted. Barring constitutional considerations, if a statute, read in context and given its ordinary meaning, clearly confers upon an inferior tribunal a jurisdiction that is enjoyed by the superior court at common law, while not depriving the superior court of its jurisdiction, it should be given effect. ${ }^{41}$

The Supreme Court of Canada set out a three-step test for determining when legislation conferring a power on an inferior tribunal contravenes s. 96 of the Constitution in Re Residential Tenancies Act, 1979. ${ }^{42}$

This case involved consideration of the Ontario Residential Tenancies Act. ${ }^{43}$ The Act contained a legislative code to govern landlords and tenants and established a Residential Tenancy Commission to oversee and enforce the obligations of landlords and tenants in Ontario. The tribunal was given wide-ranging powers and functions. A reference to the Ontario Court of Appeal was taken with respect to whether it was within the legislative authority of the Legislative Assembly of Ontario to empower the tribunal to make orders evicting tenants and orders requiring landlords and tenants to comply with obligations imposed under the Act. The Ontario Court of Appeal said no.

On appeal to the Supreme Court of Canada, Dickson J. (as he then was) dealt with the matter as follows: 
Under s. 92(14) of the B.N.A. Act the provincial legislatures have the legislative power in relation to the administration of justice in the province. This is a wide power but subject to subtraction of ss. 96 to 100 in favour of the federal authority. Under s. 96 the Govemor General has the sole power to appoint the judges of the Superior, District and County Courts in each province. Under s. 97 the judges who are to be appointed to the Superior, District and County Courts are to be selected from the respective bars of each province. Under s. 100 the Parliament of Canada is obliged to fix and provide for their salaries. Section 92(14) and ss. 96 to 100 represent one of the important compromises of the Fathers of Confederation. It is plain that what was sought to be achieved through this compromise, and the intended effect of $s .96$, would be destroyed if a province could pass legislation creating a tribunal, appoint members thereto, and then confer on the tribunal the jurisdiction of the superior courts. What was conceived as a strong constitutional base for national unity, through a unitary judicial system, would be gravely undermined. Section 96 has thus come to be regarded as limiting provincial competence to make appointments to a tribunal exercising s. 96 judicial powers and therefore as implicitly limiting provincial competence to endow a provincial tribunal with such powers. ${ }^{4}$

\section{Dickson J. went on to describe the three step test as follows:}

The first involves consideration, in the light of the historical conditions existing in 1867, of the particular power or jurisdiction conferred upon the tribunal. The question here is whether the power or jurisdiction conforms to the power or jurisdiction exercised by superior, district or county courts at the time of Confederation....

If the historical inquiry leads to the conclusion that the power or jurisdiction is not broadly conformable to jurisdiction formerly exercised by s. 96 courts, that is the end of the matter. As Rand J. noted in Dupont et al. v. Inglis et al., "Judicial power not of that type, [i.e. that exercised by s. 96 courts at Confederation] such as that exercised by inferior courts, can be conferred on a provincial tribunal whatever its primary character" (p. 542). If, however, the historical evidence indicates that the impugned power is identical or analogous to a power exercised by s. 96 courts at Confederation, then one must proceed to the second step of the inquiry.

Step two involves consideration of the function within its institutional setting to determine whether the function itself is different when viewed in that setting. In particular, can the function still be considered to be a 'judicial' function? In addressing the issue, it is important to keep in mind the further statement by Rand J. in Dupont $\mathbf{v}$. Inglis that “. . . it is the subject-matter rather than the apparatus of adjudication that is determinative". Thus the question of whether any particular function is 'judicial' is not to be determined simply on the basis of procedural trappings. The primary issue is the nature of the question which the tribunal is called upon to decide. Where the tribunal is faced with a private dispute between parties, and is called upon to adjudicate through the application of a recognized body of rules in a manner consistent with faimess and impartiality, then, normally, it is acting in a judicial capacity'. To borrow the terminology of Professor Ronald Dworkin, the judicial task involves questions of 'principle', that is, consideration of the competing rights of individuals or groups. This can be contrasted with questions of 'policy' involving competing views of the collective good of the community as a whole. (See Dworkin, Taking Rights Seriously (Duckworth, 1977) pp. 82-90.) 
If, after examining the institutional context, it becomes apparent that the power is not being exercised as a "judicial power" then the inquiry need go no further for the power, within its institutional context, no longer conforms to a power or jurisdiction exercisable by a s. 96 court and the provincial scheme is valid. On the other hand, if the power of jurisdiction is exercised in a judicial manner, then it becomes necessary to proceed to the third and final step in the analysis and review the tribunal's function as a whole in order to appraise the impugned function in its entire institutional context. The phrase - "it is not the detached jurisdiction or power alone that is to be considered but rather its setting in the institutional arrangements in which it appears as" - is the central core of the judgment in Tomko. It is no longer sufficient simply to examine the particular power or function of a tribunal and ask whether this power or function was once exercised by s. 96 courts. This would be examining the power or function in a "detached" manner, contrary to' the reasoning in Tomko. What must be considered is the "context" in which this power is exercised. Tomko leads to the following result: it is possible for administrative tribunals to exercise powers and jurisdiction which once were exercised by the $s .96$ courts. It will all depend on the context of the exercise of the power. It may be that the impugned "judicial powers" are merely subsidiary or ancillary to general administrative functions assigned to the tribunal (John East; Tomko) or the powers may be necessarily incidental to the achievement of a broader policy goal of the legislature (Mississauga). In such a situation, the grant of judicial power to provincial appointees is valid. The scheme is only invalid when the adjudicative function is a sole or central function of the tribunal (Farrah) so that the tribunal can be said to be operating "like a s. 96 court." mis

The Residential Tenancies test and the principles set out in C.B.C. v. Quebec ${ }^{46}$ and Chrysler ${ }^{47}$ were applied in MacMillan Blodel Ltd. v. Simpson. ${ }^{48}$ The majority of the court, led by the Chief Justice (La Forest, Sopinka, Gonthier and Cory JJ. concurring), ruled that the provision of the Young Offenders $A c t^{49}$ which granted to provincial courts the power to punish for contempt ex facie would otherwise be valid, except that it purported to prevent the superior courts from exercising their inherent power to punish youths for contempt ex facie. That is to say, the legislature could mandate that this power be shared, but could not take it away from the superior court and give it exclusively to the provincial court.

In her dissenting judgment, McLachlin J. (L'Heureux-Dube', Iacobucci and Major JJ. concurring) wrote that "short of impairing s. 96 courts, nothing in the Constitution suggests that Parliament should not be able to clothe inferior tribunals with $\mathrm{s} .96$ powers ancillary or necessary to their functioning." she and the Chief Justice part company - McLachlin J. suggested that the power to punish youths for contempt ex facie could be completely transferred to the provincial courts, as this was a "mere alteration or diminution of criminal jurisdiction" and not a complete exclusion. Because only the power to punish the contempt of youths was

Ibid. at 734-36.

Supra note 37.

Supra note 41.

[1995] 4 S.C.R. 725 [hereinafter Simpson].

R.S.C. 1985 , c. Y-1.

Simpson, supra note 48 at 761-62 (para. 54). 
transferred, McLachlin J. believed that this posed "no threat to the authority of the superior courts, whose authority stands firm.".s!

Lamer C.J. noted an addition to the three step test as follows:

An important addition to the Residential Tenancies test was elaborated in Sobeys Stores Lid. v. Yeomans, [1989] 1 S.C.R. 238, where Wilson J. described the characterization of the transferred power as preliminary to the first or historical branch of the test. Considering that the second and third branches of the test are designed to preserve some grants of power despite the fact that the powers were within the exclusive jurisdiction of the superior courts at Confederation, Wilson J. concluded that the test requires a strict, or narrow, approach to characterization to prevent large accretions of power (at p. 254). As many present day remedies were not available in 1867, characterization should highlight the type of dispute rather than the type of remedy sought. She also states that the same characterization must be used at each stage of the test. The complexity of the characterization question is demonstrated in the Reference re Young Offenders Act case. ${ }^{52}$

He also reiterated the importance of s. 96 as follows:

Section 96 of the Constitution Act, 1867 is regarded as a means of protecting the "core" jurisdiction of the superior courts so as to provide for some uniformity throughout the country in the judicial system. The case law has developed principles to ensure that $s .96$ would not be rendered meaningless through the use of the provincial competence to constitute, maintain and organize provincial courts staffed with provincially appointed judges having the same jurisdiction and powers as superior courts."3

The effect of Lord Atkin's judgment in Toronto Corporation v. York Corporation ${ }^{54}$ had been that any function which in 1867 had been vested in a s. 96 court must forever remain in that court. This sweeping judgment, which seriously limited provincial legislative competence to confer jurisdiction on provincial courts, was quickly limited by the Supreme Court of Canada. Duff J. declared in Reference re Adoption Act and Other Acts that the jurisdiction of inferior courts was not "fixed forever as it stood at the date of Confederation." ${ }^{55}$ In his view, the proper question to ask was whether the jurisdiction conferred upon provincial courts in these statutes "broadly conformed" to a type of jurisdiction generally exercisable by courts of summary jurisdiction rather than the jurisdiction of superior courts.

Although a statutory court has no inherent substantive jurisdiction, every court has an inherent procedural jurisdiction, which allows the court to control its own process. After reviewing English and Australian authority on this point, the Court of Appeal for New South Wales concluded in Bogeta Pty. Ltd. v. Wales that:

si Ibid. at 778 (para. 90).

$32 \quad$ lbid. at $739-40$ (para. 14).

3) Ibid. at 740 (para. 15) citing Reference Re Young Offenders Act (P.E.I.), [1991] 1 S.C.R. 252 at 264. See also Reference re Amendments to the Residential Tenancies Act (N.S.), [1996] I S.C.R. 186.

$34 \quad$ [1938] A.C. 415 (P.C.).

ss [1938] S.C.R. 398 at 399. 
The general principle, where a court is properly seized with a matter, and there is no procedure laid down which enables it to deal with the particular problem facing it, that it should devise its own procedure is, in my opinion, applicable to all courts of Petty Sessions in this day and age. Historically, inferior courts have been allowed to devise their own procedures. ${ }^{56}$

A court of Petty Sessions is presided over by a stipendiary magistrate or two justices of the peace. Section 4(b) of the Provincial Court Judges $A t^{37}$ gives a provincial court judge all the power and authority vested in a magistrate or two justices of the peace sitting together.

Much earlier, Baron Alderson declared in Crocker v. Tempest that:

The power of each Court over its own process is unlimited; it is a power incident to all Courts, inferior as well as superior; were it not so, the Court would be obliged to sit still and see its own process abused for the purpose of injustice. The exercise of the power is certainly a matter for the most careful discretion. ${ }^{58}$

In $R e W .,{ }^{59}$ Judge Fitch considered whether or not he could exclude witnesses from his courtroom, including child welfare workers. Counsel for the Director of Child Welfare objected, arguing that the Court lacked the jurisdiction to exclude the worker. Judge Fitch referred to r. 247 of the Rules of Court, which allowed the exclusion of witnesses, but acknowledged that s. 73 of the Provincial Court Act ${ }^{60}$ (now s. 76), which stated that the Rules could be applied to Provincial Court proceedings, only applied to Part 4 of the Provincial Court Act. ${ }^{61}$ Part 4 of the Act dealt with civil matters, while Part 2 (now Part 3) dealt with family matters. Nevertheless, citing $R$ v. Andersson, ${ }^{62}$ his Honour ruled that every court has inherent jurisdiction to control its own process and gave the exclusion order.

\section{STATUTORY JURISDICTION OF THE PROVINCIAL COURT OF ALBERTA (CIVIL DIVISION)}

The main distinction between superior and inferior courts is that no matter is deemed to be beyond the jurisdiction of a superior court unless it is expressly shown to be so, while no matter is deemed to be within the jurisdiction of an inferior court unless it is expressly shown to be so. ${ }^{63}$

[1977] 1 N.S.W.L.R. 139 at 149.

S.A. 1981, c. P-20.1.

(1841), 7 M. \& W. 501, 151 E.R. 864 (Exch.) at 503-504.

(1984), 54 A.R. 8 (Prov. Ct.).

R.S.A. 1980, c. P-20.

Ibid.

(1982), 70 C.C.C. (2d) 253 (Ont. Co. Ct.).

10 Hals. (4th) §713 (London: Butterworths, 1975). 
Part 4 of the Provincial Court $A c t^{64}$ is concerned with civil claims and the jurisdiction of the Civil Division of the Provincial Court of Alberta (the "Court"). Section 36 sets out the jurisdiction of the Court, while s. 37 limits it:

36(1) Subject to this Act, the Court has jurisdiction to hear and adjudicate on any claim or counterclaim

(a) for debt, whether payable in money or otherwise, if the amount claimed or counterclaimed, as the case may be, does not exceed $\$ 4000$ exclusive of interest payable under an Act or by agreement on the amount claimed, and

(b) for damages, including damages for breach of contract, if the amount claimed or counterclaimed, as the case may be, does not exceed $\$ 4000$ exclusive of interest payable under an Act or by agreement on the amount claimed.

37 The Court does not have jurisdiction to hear and adjudicate on a claim or counterclaim

(a) in which the title to land is brought into question,

(b) in which the validity of any devise, bequest or limitation is disputed,

(c) for malicious prosecution, false imprisonment, defamation, criminal conversation or breach of promise of marriage,

(d) in replevin,

(e) against a judge, justice of the peace or peace officer for any thing done by him while executing the duties of his office, or

(f) by a local authority or school board for the recovery of taxes, other than taxes imposed in respect of the occupancy of or an interest in land that is itself exempt from taxation.

In Knight v. Calgary Suzuki Inc., Judge O'Neil considered, inter alia, the meaning of "debt" in the context of s. 36 of the Provincial Court Act, ${ }^{65}$ writing:

The term "debt" has no precise meaning in law, taking its meaning from the context in which it is used and from a consideration of the purposes and circumstances surrounding its use. The act does not define it and $I$ have not read any case in which the term as used in the Act or in a parallel act in another jurisdiction has been judicially considered or defined. The most useful reference [ $]$ ] have found on this point is the section entitled the "Concept of Debt" in Creditor Debtor Law in Carada, second edition, by Professor C.R.B. Dunlop. He finds that at its broadest the term, as used in ordinary 
parlance, may include all of one's liabilities and obligations, however, in law it probably has a narrower meaning. At p. 12 the following appears:

In most situations in which lawyers use the word "debt," however, their intention is to describe something more limited than obligations or demands. Osborn's Concise Law Dictionary defines "debt" as "a sum of money due from one person to another." The Oxford Companion to Law takes a similar approach:

"Debt. That which is owed by one person to another, and particularly money payable arising from and by reason of a prior promise or contract, but also from and by reasons of any other ground of obligation. e.g. statute or order of court."

A more elaborate definition along the same line is to be found in the judgement [sic] of the New Jersey Supreme Court in Passaic Nat Bank \& Trust Co. v. Eelman (1936), 183 A 677 at 678-79:

The ordinary legal sense of the term "debt" is an obligation for the payment of money founded upon a contract, express or implied .... Its technical meaning at common law was "a sum of money due by certain and express agreement, - that for which an action for debt or indebitatus assumpsit would lie .... But it is also used in the larger sense of that which one person is obliged to pay another under any form of obligation...

This is its general signification, it includes all that is due to a person "under any form of obligation or promise".

In the main, the distinguishing characteristic of such an obligation is that it is for a sum certain or a sum readily reduced to a certainty.... Whatever the law enjoins one to pay takes the legal classification of a debt.

In Diewold v. Diewold, [1941] S.C.R. 35, the Supreme Court of Canada, in holding that the amount declared by a court as the sum a purchaser under an agreement for sale of land was entitled to pay to gain restoration of his position as purchaser was not a debt for purposes of the Farmers' Creditors Arrangement Act, the Supreme Court of Canada adopted as a definition of "debt" the following: "a sum payable in respect of a liquidated money demand, recoverable by action."

In the absence of a statutory definition or binding authority, in considering what the legislature intended by the use of a term in a statute it is appropriate to consider the objects and purpose of the legislation. Section 10 of the Interpretation Act provides:

10 An enactment shall be construed as being remedial, and shall be given the fair, large, and liberal construction and interpretation that best ensures the attainment of its objects. 6 
Because the object of Part 4 of the Provincial Court Act $t^{67}$ is to provide simple and inexpensive access to the court system for members of the public for claims under the prescribed limit, Judge O'Neil ruled that it was "reasonable to adopt from the range of possible meanings a meaning best calculated to achieve the purpose of providing a forum and a remedy for claimants with money claims within the prescribed limits who are seeking a money judgement and no other remedy. ${ }^{168}$ In the result, he adopted a broad definition of "debt" such as that applied in Diewold. ${ }^{69}$

Section 36(1)(b) states that the Court has the jurisdiction to hear any claim for damages. "Damages" is a remedy, and may properly be claimed in respect of a number of causes of action. The only cause of action specifically set out in this section is breach of contract. This section does not specify that the Court only has jurisdiction to hear claims for common law damages, leaving open the possibility of a successful claim for equitable damages.

A plain reading of s. 36(1)(b) suggests that plaintiffs may allege any cause of action for which damages might properly be awarded. For example, the Court may hear an action for negligent misrepresentation or breach of contract: Parth v. Andrews. ${ }^{70}$ In that instance, the plaintiff alleged negligent misrepresentation and breach of contract in connection with architectural guidelines and a restrictive covenant on title. Ruling that the matter brought the title to land into question, Judge Mackie referred the matter to the Court of Queen's Bench. The plaintiff appealed. Dea J. ruled that the Provincial Court was empowered to hear an action for negligent misrepresentation and breach of contract, and that the title to land was not brought into question in the case even though the subject matter of the dispute concerned the title to land.

A quantum meruit counterclaim was allowed by Judge Scott (as he then was) in Popadynetz v. Doty. ${ }^{11}$ There the plaintiff sought to recover money taken from a joint account by the defendant, with whom he had cohabited for almost four years. The defendant counterclaimed on a quantum meruit basis, alleging an implied promise by the plaintiff to pay her a reasonable sum for housekeeping, child care and bookkeeping services provided during the course of their cohabitation. Judge Scott allowed both the claim and the counterclaim. At the outset, his Honour raised the question of his jurisdiction to hear the counterclaim; he was concemed that the counterclaim raised by inference the issue of breach of promise to marry, over which the Provincial Court had no jurisdiction under s. 37 of the Provincial Court Act. ${ }^{72}$ Counsel for the defendant argued that the counterclaim was based on a breach of an implied contract to pay for services rendered, and that the defendant's betrothal to the plaintiff was irrelevant. Counsel for the plaintiff agreed that the Court had jurisdiction to deal with the counterclaim.

Supra note 60.

Knight, supra note 66 at para. 20.

See generally Diewold v. Diewold, [1941] S.C.R. 35.

(1995), 167 A.R. 212 (Q.B.), Dea J. rev'g an unreported Provincial Court decision.

[1994] A.J. No. 733 (Prov. Ct.) (Q.L.) [hereinafter Doty].

Supra note 60. 
Satisfied that none of the restrictions set out in s. 37 of the Provincial Court Act ${ }^{73}$ applied, Scott P.C.J. turned to s. 36. He wrote:

I am satisfied that this section should be given a broad and liberal interpretation having regard to the object of Part 4 of the Act. I agree with the statement of Mr. Justice MacDonald of the Alberta Court of Queen's Bench in Khokhar v. Blackburn et al. (1993), 146 A.R. 69 at p. 72 as follows:

one of the objects of the Civil Claims procedure ("Civil Claims" now being the title of Part 4) is to provide a relatively inexpensive means of resolving disputes involving amounts less than $\ldots \$ 4000$.

In keeping with that object, I am satisfied that this Court has jurisdiction under s. 36(1) of the Act with respect to this matter. ${ }^{74}$

With respect to the counterclaim, Judge Scott noted that:

The courts in recent years have recognized the principle that a person involved in a common law relationship may have a claim on a quantum meruit basis for services rendered in that relationship or on the basis of the equitable doctrine of unjust enrichment in a court of equity or in some cases may have a claim for a share of assets by reason of a constructive trust. ${ }^{75}$

He continued:

As to unjust enrichment, this Court is a statutory one and not a court of equity and no claim for share of assets on a constructive trust basis was made out in this case.

However, in recognizing there may be a claim by such a person on a quantum meruit basis for domestic services rendered, under an implied contract the courts have recognized that a corresponding benefit received by the claimant such as room and board provided by the other party to the relationship, may be taken into account in assessing any damages under this heading in favour of the claimant. $^{76}$

He allowed the counterclaim, reduced by the value of the free room and board provided to the defendant by the plaintiff, and then further reduced to $\$ 4,000$ to fit within the monetary limits of the Court. 
Returning to the language of s. 36 of the Provincial Court Act, ${ }^{77}$ was this award in respect of a "debt" owed the defendant or was it "damages"? Judge Scott's decision suggests that he found an implied contract under which the defendant agreed to supply the services and for which the plaintiff agreed to pay a reasonable amount, which implied contract was breached giving rise to a claim for damages. ${ }^{78}$

It may be that the jurisdiction of the Provincial Court to allow claims for quantum meruit will be challenged on the basis that such claims are not for damages nor debt.

In the leading case of Deglman v. Guaranty Trust Co., ${ }^{79}$ a nephew entered into an oral agreement with his aunt under which she agreed to leave him certain real property in her will in return for him rendering personal services to her. He performed the services but she did not leave him the property. He claimed against her estate. By virtue of the Statute of Frauds the oral contract was unenforceable, however, the nephew succeeded in quantum meruit. Cartwright J. said:

I agree with the conclusion of my brother Rand that the respondent is entitled to recover the value of these services from the respondent administrator. This right appears to me to be based, not on the contract, but on an obligation imposed by law.

In Fibrosa Spolka Akcyjna v. Fairbairn Lawson Combe Barbour Ltd., [1943] A.C. 32 at p.61, Lord Wright said: "It is clear that any civilized system of law is bound to provide remedies for cases of what has been called unjust enrichment or unjust benefit, that is to prevent a man from retaining the money of or some benefit delivered from another which it is against conscience that he should keep. Such remedies in English law are generically different from remedies in contract or in tort, and are now recognized to fall within a third category of the common law which has been called quasi-contract or restitution."

And at p.62: "Lord Mansfield does not say that the law implies a promise. The law implies a debt or obligation which is a different thing. In fact, he denies that there is a contract; the obligation is as efficacious as if it were upon a contract. The obligation is a creation of the law, just as much as an obligation in tort. The obligation belongs to a third class, distinct from either contract or tort, though it resembles contract rather than tort."

It is arguable that a claim for quantum meruit is not a claim for damages, but rather is a claim for restitution that takes a monetary form. On the other hand, some Canadian jurisprudence speaks of restitutionary claims giving rise to "damages at large."18 Indeed, once a plaintiff has made out a claim for restitution, courts have been willing

Supra note 60

78 Doty, supra note 71 at para. 22.

$79 \quad$ [1954] 3 D.L.R. 785 (S.C.C.).

so Ibid. at 794 .

s) See e.g.: Dickson C.J.C.'s judgment in Sorochan v. Sorochan (1986), 29 D.L.R. (4th) 1 at 7 (S.C.C.), wherein he said "Other remedies, such as monetary damages, may also be available to rectify situations of unjust enrichment"; Lambert J.A. in Atlas Cabinets \& Furniture Lid. v. National Trust Co. (1990), 68 D.L.R. (4th) 161 at 174 (B.C.C.A.), although Southin J.A. showed some reluctance. 
to give whatever relief seems appropriate in the circumstances, regardless of whether the situation woüld have been governed by equitable or common law principles.

It may also be possible to characterize a restitutionary claim as one in "debt," relying upon the language of Lord Mansfield that such claims are debts or obligations implied by law. If so, it would appear to follow that the Court could then award whatever restitutionary relief seemed appropriate, including a constructive trust.

Other statutes also govern the jurisdiction of the Provincial Court. For example, s. 41 of the Residential Tenancies $A c t^{82}$ states that the Provincial Court cannot grant an equitable remedy, an order for recovery of possession, an order directing a person to vacate premises, or any relief or remedy required by the Act to be granted by the Court of Queen's Bench. Similarly, s. 46 of the Mobile Home Sites Tenancies Act ${ }^{83}$ precludes the Provincial Court from granting an equitable remedy.

Subsection 11(1) of the Unfair Trade Practices $A c t^{84}$ sets out a cause of action for consumers who have entered into a consumer transaction and have suffered damage or loss due to an unfair act or practice. Subsection 11(2) sets out the available remedies. These include an order declaring that the act or practice complained of is an unfair act or practice; damages for damage or loss suffered; punitive or exemplary damages; an order for specific performance, restitution or rescission of the consumer transaction; an injunction; or any other relief. Subsection 12(1) allows an action brought under subsection 11(1) to be commenced under Part 4 of the Provincial Court Act, ${ }^{85}$ subject to the jurisdiction of the Provincial Court.

Maxwell on The Interpretation of Statutes suggests that statutes conferring jurisdiction on courts ought to be given "beneficial construction." ${ }^{86}$ This supports an argument that under s. 36 of the Provincial Court Act ${ }^{87}$ (subject to s. 37 and restrictions found in other acts) the Court has jurisdiction to give any remedy (including equitable relief) appropriate to an action for debt, and to hear any cause of action (including equitable causes of action) for which damages (including equitable damages) would be appropriate.

If this interpretation is correct, and the Legislature has given the Provincial Court limited equitable jurisdiction, the question arises whether the Legislature could grant the Court such jurisdiction.

R.S.A. 1980 , c. R-15.3.

S.A. 1982, c. M-18.5.

R.S.A. 1980 , c. U-3.

Supra note 60.

P. St. J. Langan, ed., 12th ed. (Bombay: Tripath, 1969) at 100.

Supra note 60. 
Applying the three-step test in Residential Tenancies ${ }^{88}$ and the preliminary characterization step in Sobey Stores, ${ }^{89}$ it seems clear that the analysis will be carried to the third step. With respect to the third step, if the power is merely subsidiary or ancillary to general administrative functions assigned to the tribunal, or if the power is necessarily incidental to the achievement of a broader policy goal of the legislature, the grant of power will be valid. However, if the power is the sole or central function of the inferior court, then the court will be operating like a section 96 court and the grant of power will be invalid.

It is submitted that a case can be made that the grant of limited equitable jurisdiction is necessarily incidental to the achievement of the broader policy goal of providing an expeditious and inexpensive forum for the adjudication of relatively small disputes, and that, as McLachlin J. wrote for the minority in MacMillan Blodel Ltd. v. Simpson, this is a mere "alteration or diminution" 90 of the superior court's jurisdiction, which poses "no threat to the authority of the superior courts, whose authority stands firm." point was that there is nothing in the Constitution preventing legislatures from clothing inferior courts with s. 96 powers ancillary or necessary to their function. Consequently, it is arguable that the exercise of a limited equitable jurisdiction by the Provincial Court (Civil Division) does not offend the Constitution.

The opposing argument is that the Legislature has not invested the Provincial Court (Civil Division) with any equitable jurisdiction through s. 36 of the Provincial Court $A c t^{22}$ because, to use the words of Dickson J. (as he then was) in C.B.C. v. Quebec, s. 36 is not a "clear and unambiguous statutory provision."

\section{EQUITABLE JURISDICTION OF THE PROVINCIAL COURT (CIVIL DIVISION)}

It has been often been assumed that the Provincial Court has no equitable jurisdiction. In Crowe, Duhamel, Manning v. Allford, Provincial Court Judge, the plaintiffs sought an order of mandamus compelling a judge of the Provincial Court to enter a default judgment in favour of the plaintiff law firm in an action brought by the firm for unpaid fees. The order was granted. Holmes J. considered whether or not a Provincial Court judge could order taxation, observing that:

The power to refer a lawyer's bill for taxation has its historical background as equitable relief in the Court of Chancery [citation omitted]. It is trite to say that the judges of the Provincial Court have no

Residential Tenancies, supra note 42.

Sobey Stores Ltd. v. Yeomans and Labour Standards Tribunal (N.S.), [1989] 1 S.C.R. 238 [hereinafter Sobey Stores].

Simpson, supra note 48 at 778 (para. 89, McLachlin J. quoting McEvoy v. A.G. (N.B.), [1983] 1

S.C.R. 709 at 722 ).

Simpson, supra note 48 at 778 (para. 90).

Supra note 60.

C.B.C. v. Quebec, supra note 37 at 648. 
equitable powers. For a Provincial judge to direct a taxation in Queen's Bench is beyond his jurisdiction. ${ }^{94}$

It is respectfully submitted that the question is not whether the Provincial Court has a broad equitable jurisdiction similar to that of the Court of Queen's Bench, but rather whether by statute the Legislature has given the Provincial Court some equitable jurisdiction. Holmes J. is no doubt correct in ruling that the Provincial Court has no power to order taxation, however, the proposition that the Provincial Court cannot do one particular equitable thing does not, it is submitted, lead to the conclusion that it can do nothing equitable.

In Knight, ${ }^{95}$ Judge O'Neil considered whether the Provincial Court had any equitable jurisdiction. In that case, the plaintiff paid $\$ 1,000$ on a used car, the total price of which was $\$ 4,800$. The deal fell through and the defendant dealership refused to return the $\$ 1,000$. His Honour considered whether the $\$ 1,000$ was a reasonable preestimate of damages or whether it was a penalty. Quoting from the judgment of Lord Denning in Stockloser v. Johnson, ${ }^{96}$ he observed that in certain cases equity would relieve against forfeiture, particularly where the amount forfeited was out of all proportion to the damage. Although the sales agreement between the parties provided for forfeiture of the down-payment or deposit where the buyer repudiated the agreement, O'Neil P.C.J. ruled that because there was no evidence that defendant had demanded the balance due, the forfeiture clause did not apply. He further found that the amount claimed as a deposit was excessive, as it amounted to almost one-quarter of the purchase price. The defendant argued that the Provincial Court did not have any jurisdiction to grant the equitable remedy of relief from forfeiture. Judge O'Neil dealt with that argument this way:

The defendant argues that the Provincial Court of Alberta does not have jurisdiction to grant equitable relief and consequently cannot relieve against forfeiture. The defendant cites no authority for this proposition; apparently treating it as an accepted truism. However, it appears to be based on the reasoning that the Provincial Court of Alberta is a creature of statute and can only have the powers conferred on it by statute and, since the Provincial Court Act (the "Act") does not specifically mention equitable relief, the jurisdiction to grant equitable relief was not included, however, it must be noted that the Act does not specifically grant jurisdiction to grant common law remedies either. In view of this, what jurisdiction does the Court have.

Relief from forfeiture is a power that is now granted in Sec. 10 of the Judicature Act. Sec. 10 confers the power to relieve against forfeiture on the "Court," which expression is defined in that act as the Court of Queen's Bench and the Court of Appeal and does not include the Provincial Court. The equivalent power existed at common law before it became statutory. It was part of the equitable jurisdiction inherent in courts of equity and it was probably granted occasionally by common law 
courts as early as the fourteenth century $-A$ Concise History of the Common Law - T.F.T. Plucknett

( 2 ed.) p. 606, well before the Court of Chancery became the main or only dispenser of equity."

Continuing, he noted that s. 37 of the Provincial Court $A c t^{98}$ did not preclude the Court from relieving from forfeiture. He then considered the meaning of "debt" reasoning that he was justified in classifying the sum claimed as a debt due to the plaintiff from the defendant. His Honour concluded as follows:

While the Act does not specify what rules of decision are to be applied, it must be assumed that, except where expressly limited decisions of the Court are to be reached by applying the law that is applied by the courts of Alberta generally in "hearing and adjudicating claims and counterclaims for debt" including the rules on which liability for debt is based and also including the rules that provide a defense to such claims or which modify or limit liability upon them.9

In the result, the Court granted equitable relief against forfeiture.

Judge O'Neil's statement that "the Act does not specifically grant jurisdiction to grant common law remedies either" is interesting. Subsection 36(1)(b) gives the Court jurisdiction to hear and adjudicate any claim or counterclaim for damages. With respect, this is a grant of jurisdiction to award damages, for adjudicating a claim for damages means that the claim must be either granted or denied.

\section{EQUITABLE CAUSES OF ACTION}

If Part 4 of the Provincial Court Act ${ }^{100}$ gives the Provincial Court (Civil Division) jurisdiction to hear any cause of action (legal or equitable) which may give rise to damages, what equitable causes of action may the Court hear?

Hanbury and Maudsley state in Modern Equity that damages are available for breach of trust. Damages are also available for breach of fiduciary duty. ${ }^{101}$

"Equitable compensation," which the courts appear to use interchangeably with equitable damages, is a monetary award, but is different than common law damages. In Canson, La Forest J. distinguished between common law damages and equitable compensation as follows:

There can be little doubt that damages come within the province of the common law.... Damages are a monetary payment awarded for the invasion of a right at common law. Equity aimed at restoring a person to whom a duty was owed to the position in which he or she would have been [in] had the duty not been breached. This it did through a variety of remedies, including compensation. 
The difference between damages and restitution was abundantly clear in cases of breaches of trust, and in that context the following statement of James and Baggallay L.JJ. in Ex parte Adamson (1878), 8 Ch. D.807, at p. 819 (C.A.), appears unexceptionable:

The Court of Chancery never entertained a suit for damages occasioned by fraudulent conduct or for breach of trust. The suit was always for an equitable debt or liability in the nature of debt. It was a suit for the restitution of the actual money or thing, or value of the thing, of which the cheated party had been cheated. ${ }^{102}$

It is interesting to note the language of the Court of Appeal in Ex parte Adamson. If the suit is framed as being for an equitable debt or liability in the nature of debt, it arguably would fall within s. 36 (1)(a) of the Provincial Court Act. ${ }^{103}$

Equitable damages were described by McLachlin J. in Norberg v. Wynrib, the infamous "sex for drugs" case, as follows:

In so far as the action concerns medical malpractice, principles of assessment of damages in contract and tort may be of assistance, at least by analogy. In so far as it concerns wrongful sexual exploitation, we enter into the exclusive terrain of equity.

It therefore seems appropriate in this case to assess damages according to the principles which generally govern damages for breach of fiduciary duty, having regard to the admonition in Canson that the remedy awarded need not be confined to that given in previous situations if the requirements of fairness and justice demand more, and that reference to the principles of assessment in contract and tort may be of assistance in so far as they are relevant.

As discussed in Canson, the goal of equity is to restore the plaintiff as fully as possible to the position he or she would have been in had the equitable breach not occurred.... Traditionally, equity made the defaulting trustee who had mismanaged a fund, for example, restore the entire fund, and would not countenance deductions for market fluctuations or failure of the beneficiary to mitigate or take appropriate care, as would the law of tort or contract. This is not a case where the traditional equitable remedies of restitution and account are available. Restoration in specie is not possible. And the plaintiff's loss is not economic. Where these remedies are not available, equity awards compensation in their stead.... In awarding damages the same generous, restorative remedial approach, which stems from the nature of the obligation in equity, applies. ${ }^{104}$

It should also be noted that equitable damages are calculated as at the date of trial, rather than the date of breach or loss. 


\section{EQUITABLE REMEDIES}

If Part 4 of the Provincial Court Act ${ }^{105}$ gives the Provincial Court (Civil Division) the jurisdiction to give any remedy (legal or equitable) for debt, what equitable remedies are available?

Equitable compensation or damages has been considered above.

The major equitable remedies, however, are specific performance, injunction, rescission, rectification and accounting. As seen above, in a debt action Judge O'Neil essentially relieved the plaintiff from forfeiture. It is difficult to see how any of these major equitable remedies would be appropriate to a debt action.

Moreover, there is sometimes a reluctance to employ equitable remedies. Roscoe Pound wrote in "The Theory of Judicial Decision":

We hesitate to employ restitution or coercion of specific action or prevention until we are convinced that our common-law remedial technique will not suffice.... This attitude colors our whole administration of justice. ${ }^{106}$

New Zealand jurist Grant Hammond wrote in "Rethinking Remedies: The Changing Conception of the Relationship between Legal and Equitable Remedies" in J. Berryman, ed., Remedies: Issues and Perspectives that there is an "artificial primacy" in common law countries, characterized by a marked preference for common law damages awards; equitable relief ranks second, while declaratory relief comes in a distant third. ${ }^{107}$

\section{EQUITABLE PRINCIPLES}

Through the years, courts have developed a number of maxims representing equitable principles, which are invoked when the court wishes to apply a particular equitable principle. The major equitable maxims are:

Equity will not suffer a wrong without a remedy.

Equity follows the law.

Whomever seeks equity must do equity.

Whomever comes to equity must come with clean hands.

Where the equities are equal the law prevails.

Where the equities are equal the first in time prevails.

Equity imputes an intention to fulfil an obligation.

Equity regards as done that which ought to be done.

Equity is equality.

Equity looks to the intent rather than the form.

Delay defeats equities. 


\section{Equity acts in personam.}

There are a number of concepts known to both law and equity, however, because of the difference between legal and equitable principles, they may be applied differently. For example, the doctrine of mistake exists in both law and equity. The application in each can yield different results. ${ }^{108}$ Another difference may be found in the concept of set-off. In Telford v. Holt, ${ }^{109}$ the Supreme Court of Canada ruled that as between the parties there was no set-off in law, but that there was set-off in equity.

Other equitable principles include unconscionability, undue influence and estoppel. Given the unsophisticated nature of most of the parties who appear before the Provincial Court (Civil Division), it is difficult to see how the Court can operate without at least implicitly exercising equitable principles. The phrase "equitable principles," after all, means nothing more than doing what is necessary to achieve a just and fair result. Indeed, Judge Thomson of the Ontario Provincial Court has suggested that in the Provincial Court equitable principles are appropriately employed any time the judge may use his or her discretion.

\section{JURISDICTION REGARDING PREROGATIVE WRITS}

The prerogative writs were born out of the need for the King's courts (such as King's Bench, Common Pleas, Court of the Exchequer and Chancery) to keep all lesser courts, tribunals and officials within the limits of their jurisdictions; they provided the King's subjects with remedies in the event that an inferior body exceeded its jurisdiction. Where the body found to have exceeded its jurisdiction was a court of record, the writ of appeal was used. In most cases, however, the King's courts were called upon to deal with inferior bodies which were not courts of record or which exercised quasi-judicial functions.

Control of authority was originally regarded as a royal prerogative, but by the time Coke was Chief Justice of the King's Bench in the early seventeenth century, this authority had been passed on to the King's courts. The oldest of the prerogative writs is that of prohibition, developed in the thirteenth century. One of the most modern prerogative remedies is the declaration. The declaration is related to the petition of right against the Crown, but until 1883 could only be granted in conjunction with another remedy. Subsequently, however, the declaration became a remedy in its own right.

The so-called prerogative writs are called "prerogative" because they were originally the prerogative of the King. At least since about 1600, they have been exercised by superior courts, in keeping with those courts' inherent supervisory jurisdiction. ${ }^{110}$ For this reason, it is doubtful that an inferior court would be able to exercise these writs. Indeed, because the prerogative writs were historically exclusively exercised by superior

See e.g. McMaster University v. Wilchar Construction Lid. (1971), 22 D.L.R. (3d) 9 (Ont. H.C.J.), aff' (1973), 69 D.L.R. (3d) 400 (C.A.).

(1987), 41 D.L.R. (4th) 385.

See generally Baker, supra note 2 at 164-73. 
courts, any attempt to grant to an inferior tribunal the power to dispense prerogative writs would face a steep hurdle in passing the first step of the Residential Tenancies test.

\section{ONTARIO}

The situation in Ontario is significantly different from Alberta. Until 1984, small claims court was governed by the Small Claims Courts Act." ${ }^{11}$ This Act was replaced in 1984 by the first Courts of Justice Act, ${ }^{112}$ which was extensively amended in 1989. Section 57 of the Small Claims Courts Act stated that "[t]he judge shall hear and determine in a summary way all questions of law and fact and may make such order or judgment as appears to him just and agreeable to equity and good conscience." Subsection 59(1) of that Act gave the small claims court power to "grant relief, redress or remedy, or combination of remedies, either absolute or conditional, including the power to relieve against penalties and forfeitures, in as full and ample a manner as might be done in the like case by the Supreme Court." Section 57 was considered by the Ontario Court of Appeal in Smith v. Galin by Mackay J., who wrote:

This statutory provision ... does not, in my opinion, entitle the judge to disregard the general principles of law, but may very well be interpreted to clothe the Court with jurisdiction to disregard technical defects which would defeat the justice of the claim. ${ }^{113}$

On appeal from the Provincial Court in Attorney-General of Canada v. Khimani, ${ }^{114}$ Van Camp J. ruled that s. 57 did not give the Provincial Court the power to depart from legal principle. However, in reversing the Provincial Court, the Divisional Court did not rule expressly on the issue of the equitable jurisdiction of the lower court.

Subsection 78(3) of the 1984 Courts of Justice Act ${ }^{115}$ gave the Provincial Court (Civil Division) the jurisdiction to "hear and determine in a summary way all questions of law and fact and may make such order as is considered just and agreeable to good conscience." Although this is similar to s. 57 of the Small Claims Courts Act, ${ }^{116}$ the reference to "equity" was removed. Instead, s. 109(3) reserved the right to dispense equitable relief to the Supreme, District and Unified Family Courts. Section 109 provides:

109(1) Courts shall administer concurrently all rules of equity and the common law.

(2) Where a rule of equity conflicts with a rule of the common law, the rule of equity prevails.

$\begin{array}{ll}\text { I1' } & \text { R.S.O. 1980, c. } 476 . \\ 112 & \text { S.O. 1984, c. } 11 . \\ 113 & {[1956] \text { O.W.N. } 432 \text { at } 434 .} \\ 114 & \text { (1985), 50 O.R. (2d) } 476 \text { (Div. Ct.). } \\ 115 & \text { Supra note } 112 . \\ 116 & \text { Supra note } 111 .\end{array}$


(3) Unless otherwise provided, only the Supreme Court, the District Court and the Unified Family Court may grant equitable relief.

In Moore v. Canadian Newspapers Co., ${ }^{117}$ Rosenberg J. reviewed the authorities and ruled that under the 1984 Courts of Justice Act ${ }^{118}$ the Provincial Court of Ontario had no jurisdiction to grant equitable relief. In that instance, Rosenberg J. was hearing an appeal from a Provincial Court order that the appellant publish a retraction and an apology in respect of a libel.

Although s. 109(3) makes it clear that the Provincial Court of Ontario could not grant equitable relief, the Provincial Court of Ontario struggled with the issue of whether it could still apply rules of equity or equitable principles. Judge Vogelsang ruled in McGee (Irwin) v. Irwin that the restriction in S. 109(3) "relates only to accepted manifestations of equity as remedies. Obvious examples of these remedies would be specific performance, declaratory and injunctive relief, restitutionary orders and, perhaps, rectification." 119

The Ontario Provincial Court (Family Division) ruled in Stephenson v. Willoughby $y^{120}$ that although it could not grant equitable relief, it could still apply rules of equity, such as the equitable defence of lâches. ${ }^{121}$ However, that same court ruled in Thrasher v. Stevenson ${ }^{122}$ that S. 109 of the 1984 Courts of Justice Act ${ }^{123}$ prevented the court from applying equitable estoppel. ${ }^{124}$

In Re Henning and Weber, Thomson P.C.J. reasoned that although the Provincial Court could not grant equitable relief, a judge could look to equitable principles when deciding to exercise a discretion expressly granted by statute. ${ }^{125}$ In support, her Honour cited s. 9(2) of the Provincial Courts Act: ${ }^{126}$

9(2) Where jurisdiction is conferred on a judge, justice of the peace or provincial court, in the absence of express provision for procedures therefor in any Act, regulation or rule, the judge, justice of the peace or provincial court shall exercise the jurisdiction in any manner consistent with the due administration of justice.

The functional equivalent in Alberta is s. 76 of the Provincial Court Act: ${ }^{127}$

(1990), 69 O.R. (2d) 262 (Gen. Div.).

Supra note 112.

(1986), 8 C.P.C. (2d) 86 at 91.

[1987] O.J. No. 1801, Main P.C.J. (Q.L.).

Although of course this defence is only a defence to a claim for an equitable remedy: $R$. Megarry \& P.V. Baker, eds., Snell's Principles of Equity, 27th ed. (London: Sweet \& Maxwell, 1973) at 33. [1985] O.J. No. 819, Abbey P.C.J. (Q.L.).

Supra note 112.

See also Ontario (Support and Custody Enforcement, Director) v. Innis, [1989] O.J. No. 1025, Nevins P.C.J. (Q.L.); and Ridding v. Morrison (1982), 31 R.F.L. (2d) 97, Nasmith P.C.J.

(1984), 45 O.R. (2d) 366 at 370.

R.S.O. 1980 , c. 398.

Supra note 60. 
76(1) The practice and procedure of the Court shall be as provided in this Act and the regulations.

(2) Where this Act and the regulations do not provide for some specific practice or procedure and the practice or procedure is necessary to ensure an expeditious and inexpensive resolution of the matter before the Court, the Court may, in its discretion, apply the Alberta Rules of Court, modified or varied as need be.

Although the Alberta provision is not as broad as its Ontario counterpart, as it only gives the Court the discretion to apply, modify or vary a practice or procedure found in the Rules of Court, it is arguable that Judge Thomson's reasoning should be applicable to the situation in Alberta as well.

The 1984 Courts of Justice Act was extensively amended in 1989 in connection with an overhaul of the Ontario court system, which included the creation of a new Small Claims Court. Section 11 of the new Courts of Justice Act ${ }^{128}$ sets out the jurisdiction of the Ontario Court (General Division):

11(1) The Ontario Court (General Division) is continued as a superior court of record under the name Ontario Court (General Division) in English and Cour de l'Ontario (Division générale) in French.

(2) The General Division has all the jurisdiction, power and authority historically exercised by courts of common law and equity in England and Ontario.

\section{Section 22 deals with the Small Claims Court:}

22(1) The Small Claims Court is continued as a branch of the General Division under the name Small Claims Court in English and Cour des petites créances in French.

Section 96 of the new Act dealt with which courts were competent to grant equitable relief:

96(1) Courts shall administer concurrently all rules of equity and the common law.

(2) Where a rule of equity conflicts with a rule of the common law, the rule of equity prevails.

(3) Only the Court of Appeal, the Unified Family Court and the Ontario Court (General Division) may grant equitable relief, unless otherwise provided.

The jurisdiction of the Small Claims Court is then restricted by s. 23.:

23(1) The Small Claims Court,

(a) has jurisdiction in any action for the payment of money where the amount claimed does not exceed the prescribed amount exclusive of interest and costs; and 
(b) has jurisdiction in any action for the recovery of possession of personal property where the value of the property does not exceed the prescribed amount.

Interpreting the new Act, James Prov. Div. J. noted in Reed v. Reed ${ }^{129}$ that the Provincial Division of the Court of Justice did not have equitable parens patriae jurisdiction. In support of this conclusion, his Honour observed that the Court of Justice (Provincial Division) was not a court of equity, and that under the new Act, only the Court of Justice (General Division) had such jurisdiction. Similarly, the Provincial Court ruled in Ontario (Director of Family Support Plan) v. Freyseng that it did not have the jurisdiction to grant equitable set-off. ${ }^{130}$

However, in Ontario the Small Claims Court is considered a branch of the Ontario Court of Justice (General Division) and is generally considered to be competent to grant equitable relief under s. 96(3) of the new Courts of Justice Act. ${ }^{131}$ In Arnett v. Rail Canada Traffic Controllers, Judge Thomson explained it this way:

This Court is a branch of the Ontario Court (General Division). Its President is the Chief Justice and its judges are those in the General Division: Section 21 of the Courts of Justice Act, 1984 as amended. The Court has jurisdiction in "any action for the payment of money where the amount claimed does not exceed $\$ 3,000.00$ [later $\$ 6,000$ ] exclusive of interest and costs: Section $22(1)$, Courts of Justice Act.

Under 109(3) of the Courts of Justice Act, ... [t]he Ontario Court (General Division) Small Claims Court has jurisdiction to grant equitable relief is [sic] claimed. ${ }^{132}$

\section{BRITISH COLUMBIA}

The governing legislation in British Columbia is the Small Claims Act ${ }^{133}$ and the Law and Equity Act. ${ }^{134}$ The stated purpose of the Small Claims Act, according to s. 2(1) of that $A c t$, is "to allow people who bring claims to the Provincial Court to have them resolved and to have enforcement proceedings concluded in a just, speedy, inexpensive and simple manner." Subsection 2(2) allows the Provincial Court to "make any order or give any direction it thinks necessary to achieve the purpose of this Act," subject to the $A c t$ and the rules.

The Provincial Court of British Columbia has a wider jurisdiction than its Alberta counterpart, as s. 3 of the Small Claims Act gives it jurisdiction over claims for debt or damages, recovery of personal property, specific performance of agreements relating to services or personal property, and relief from opposing claims to personal property, so long as the amount claimed or the value of the property or services is $\$ 10,000$ or 
less. Subsection 3(2) excludes from the court's jurisdiction actions for libel, slander and malicious prosecution. In R.K. v. McBride, Judge Mondin wrote:

On an annual basis approximately 46,500 actions - being some 50 percent of all of the civil claims filed in the province of British Columbia - are commenced in the civil division of the Provincial Court. Bearing in mind the purpose of the Small Claim Court ... and being familiar as a judge of this court with the type of claims which are typical in the overall caseload, there is no doubt it would work a very real hardship if it were determined that this court does not possess the substantive equitable jurisdiction which it presently exercises routinely, whether in granting damages for unjust enrichment or in quantum meruit, or in maintaining equitable defences like estoppel. But forming the opinion that a substantive jurisdiction is desirable in the interest of administering justice in a just, speedy, inexpensive and simple manner does not create that jurisdiction. One must ask whether it arises by statute. $^{135}$

Sections 4, 5, 6, 7, and 41 of the British Columbia Law and Equity Act ${ }^{136}$ vest jurisdiction regarding both equitable claims and defences in "all courts." Unlike the Alberta Judicature Act, ${ }^{137}$ "court" is not restrictively defined so as to exclude the Provincial Court.

\section{CONCLUSION}

Although it has an inherent procedural jurisdiction, as an inferior statutory court the Provincial Court of Alberta has no inherent substantive jurisdiction. The Judicature Act codifies the fusion of law and equity in Alberta, providing that courts may hear both legal and equitable causes of action and grant both legal and equitable relief. However, "court" is defined in that Act to mean only the Court of Appeal and the Court of Queen's Bench.

Part 4 of the Provincial Court Act ${ }^{138}$ sets out the basic jurisdiction of the Provincial Court (Civil Division). Subject to s. 37, s. 36 states that the Court may hear and adjudicate any claim or counterclaim for "debt" or "damages." It is submitted that it is arguable that the court may grant any relief for an action in debt, and that "debt" may include equitable debt, and may hear any cause of action for which damages, including equitable damages, might properly be awarded, subject to s. 37 .

Other acts specifically state that the Provincial Court may not grant equitable relief. If the Provincial Court has no equitable jurisdiction in any event, it would seem to be unnecessary for the Legislature to specifically state, for example, that for the purposes of the Residential Tenancies Act, ${ }^{139}$ the Provincial Court cannot grant equitable relief. This lends support to the above interpretation of s. 36 of the Provincial Court Act. 
Further support may be found in Maxwell on The Interpretation of Statutes where the author suggests that statutes relating to the jurisdiction of a court may receive "beneficial construction." 140 Such an interpretation of s. 36 arguably best meets the goal of the Provincial Court (Civil Division) of providing a relatively inexpensive means of resolving disputes involving amounts less than $\$ 4000$.

If the court has no equitable jurisdiction whatever, this may cause potential litigants to decide not to proceed with their valid claims because the relief to which they would be entitled could only be obtained from the Court of Queen's Bench. Judge Mondin of the British Columbia Provincial Court made this point in R.K. v. McBride, writing:

In my view the "Small Claims" name is unfortunate in that it diminishes the significance of these claims for the litigants; as a judge in this court I know that for a great many if not most litigants the amount and the principles involved are not "small" from their perspective. Are we then to tell them that their claim or defence is not deserving of the same procedural integrity as that which exists in the Supreme Court? By that I don't mean the formal procedures of discovery and so on, but rather the action demanded of the court in response to diverse and often unforeseeable circumstances if justice is to be done, and is to be seen to be done. Are we to tell them that the Supreme Court judge has been given a greater procedural arsenal to ensure that justice is done for the "big" claims? The proposition is repugnant, and I cannot believe it was the intent of the Legislature when creating this court. ${ }^{141}$

In the end, this may be the most compelling argument for interpreting the Provincial Court $A c t^{142}$ as granting a limited equitable jurisdiction. Otherwise, we may have the situation commented on by Augustine Birrell at the turn of the century in "Changes in Equity, Procedure, and Principles," in A Century of Law Reform, namely:

The distinction between Law and Equity is one which will never be grasped by the lay mind. This need not trouble us. It was a relief to a litigant in the Old Queen's Bench who had lost his case to be able to exclaim as he left Westminster Hall, "This may be law, but it is not equity," whilst the disappointed Chancery suitor, who had been refused the relief he had prayed, could always ejaculate "If this be equity, give me law."143

143 (London: MacMillan, 1901) (reprinted South Hackensack: Rothman Reprints, 1972) at 178. 